\title{
The implementation of pictures media to improve paragraph writing skill
}

Siti Sulastri

SMAN 1 Magetan, Kabupaten Magetan, Indonesia

\begin{tabular}{l} 
Article Info \\
\hline Article history: \\
Received January 12, 2019 \\
Revised March 20, 2019 \\
Accepted June 16, 2019 \\
\hline
\end{tabular}

\section{Keywords:}

pictures;

paragraph writing skill;

motivation;

classroom action research

\begin{abstract}
The main objectives of the research are: (1) to identify whether pictures can improve students' paragraph writing skill for the tenth graders of Senior High School in SMAN 1 Magetan; (2) to identify the students's motivation when the pictures are used to teach paragraph writing skill for the tenth graders of Senior High School in SMAN 1 Magetan in academic year 2018/2019. The Research was carried out at SMAN 1 Magetan, East Java, in second semester from January 2019 to May 2019. The subjects of the research are 34 students of grade X. MIPA -1 consisting of 14 boys and 20 girls. The data were obtained from several techniques: test, observation, interview, questioners, and document analysis. To analyze the qualitative data, I used interactive model; while to analyze quantitative data, I applied a descriptive statistics. It is done by comparing the mean of pre-test and post-test. There are some findings of the research which include: pictures can improve students' paragraph writing skill for the tenth graders of Senior High School in SMAN 1 Magetan. The improvements of paragraph writing skill comprise: (1) writing topic sentence; (2) writing supporting sentences; and (3) using correct grammar and cohesive devices (conjunctions). In addition, the students' motivation is better when the pictures are used to teach paragraph writing skill for the tenth graders of Senior High School in SMAN 1 Magetan. Based on the result of the research, it can be concluded that applying pictures as media can improve students' paragraph writing. Therefore, it is recommended that the teachers can use pictures as an effective media to improve the students' paragraph writing skill.
\end{abstract}

Copyright (C) 2019 Department of English Teaching. All rights reserved.

Corresponding Author:

Siti Sulastri

Education Department of East Java,

Senior Hight School 1 Magetan

Jalan Monginsidi, Magetan

Email: sisulmgt.eng2016@gmail.com

\section{INTRODUCTION}

The main text format consists of a flat left-right columns on A4 paper (quarto). The margin text from the left Paragraph writing is difficult to learn. It needs specialized skills that include the ability to express the writeres opinions or thoughts clearly and efficiently. It is reasonable as it is stated by Heaton (1989: 35) that paragraph writing skills are complex and sometimes difficult to teach, requiring mastery not only of grammatical and rhetorical devices but also of conceptual and judgemental elements. The following are skills necessary for good paragraph writing classified into four general components or main areas: (1) Writing a topic sentence: the ability to write correct and appropriate main idea or opinion; (2) Writing supporting sentences: the ability to develop main idea or topic sentence by adding more information; (3) Writing grammatical sentences: the ability to construct the sentence (word order, verb and noun systems, modifiers, phrases, clauses, etc.); and (4) Writing cohesive devices: the ability to use conjunction.

The statement above is supported by Zemach \& Rumisek (2005: iv) stating when students write the types of paragraph, they practice paragraph with writing topic sentence and supporting sentences to develop 
the main idea using appropriate grammar and transisional devices in the paragraph body. What follows a topic sentence are a number of supporting sentences that develop the main idea with specific details (Richard, 2008: 34).

Based on Balley (2003: 55), to be clear and readable of the whole paragraph writing, the writer has to use cohesive devices that are focused and emphasised with linking phrases. Beth and Lindy (1998: 1) tate that a sound understanding of grammar, like a brick wall, must be built one level at a time. The students cannot miss a level and go on to the next. If they master each level as it is presented, they will find that grammar is neither as difficult nor as complicated as they may have thought. The students will also find, as they work through the writing sections of the text, that by applying their knowledge of grammar they can greatly improve their writing skills. So they can create a good writing in sentences, paragraphs, nd texts. It is proved by Brown (2000: 342) in his microskills that paragraph writing is using such as; writing a topic sentence, writing supporting sentences, using cohesive devices correctly, and using aceptable grammatical system (e.g., tenses, agreements, pluralizations). Up to now English teaching and learning model practiced in the classroom has not given significant proportion to writing yet. Most of the teachers have not given lot of opportunities to the students to practice and develop paragraph writing skill and have not given correct treatment to the studentse paragraph writing problem. Another study is conducted by Riyanto (2001: 3), who found that most of the studentse problems in writing are due to some factors: lack of understanding of English grammar, and lack of practice. Sabilah (1999: 3) reported that the students ${ }^{\text {ee }}$ ability in English writing skill was still far from the target stated in the curriculum. They did not have the ability to express their ideas in written form. The students have less idea in developing sentences and often lack good transition between topics (Yang 1995: 29).

Based on the preliminary observation on the teaching and learning process and interviews between the writer and the students, the writer found that there are some problems that arise in studentse paragraph writing. The students, difficulty in paragraph writing skill was caused by three factors. These factors were the students, teacher, and the class situation as follows: (1) From the students, it is related to less of practicing to get the ideas. They did not feel confident in their paragraph writing and did not encourage themselves to develop their ability in paragraph writing; (2) From the teacher"s factor, it could be said that the use of inappropriate technique which didn ${ }^{e} t$ help the students understand the paragraph writing better.

The teacher presented the lesson in the book and asked students to make paragraph by answering the questions. The teacher gave less of the paragraph writing practices to the students; and (3) the last factor is the class situation. The writing class is teacher-centered, the students depend too much on the teacheres instructions. The instructions from the teacher made the students lazy and sleepy so the class became uncomfortable. Facing the problems above the teacher finds out the ways or strategies to solve the problem, so that the students can improve their paragraph writing skill and get high score in writing test. The writer thinks that teaching paragraph writing must encourage and motivate the students to learn actively, creatively, effectively, and enjoyably. It may be done by using an appropriate media in teaching paragraph writing to the students. To build students ${ }^{\text {ee }}$ motivation, the teacher should choose an appropriate teaching media in learning and teaching process. Brinton in Murcia (1991: 459) said that teaching media is anything that the teachers use to help the students to understand the lesson. As a tool for language learning and teaching, media undoubtedly always facilitates the task of language learning. One of the teaching media which is helpful to teach paragraph writing is picture postcards. Rava (1998: 58) states that pictures carry cultural, artistic and historical information. Hence, the students will be able to get a lot of idea and information through pictures. They can also make their own pictures by getting the pictures from many sources such as magazines, books, or even internet. So, it is very easy for the teachers to provide them as the teaching media in the classroom.

\section{RESEARCH METHOD}

This study is a Classroom Action Research with four stages. Action research is a systematic procedure done by teachers (other individuals in educational setting) to gather information about,

English Teaching Journal, Vol. 7, No. 1, June 2019: 1 - 8 
and subsequently improve, the ways their particular educational setting operates, their teaching and their students learning (Milis in Creswell, 2008: 105). Elliott (1991: 75) explains that action research is the process through which teachers collaborate in evaluating their practice jointly; raise awareness of their personal theory; articulate a shared conception of values; try out new strategies to render the values expressed in their practice more consistent with the educational values they espouse; record their work in a form which is readily available to and understandable by other teachers; and thus develop a shared theory of teaching by researching practice.

There are four stages in classroom action research that is stated by Kurt Lewin as quoted by Arikunto (2006: 92) that classroom action research consists of four basic components, those are planning, acting, observing, and reflecting. 1) Planning Stage. In the planning stage, the collaborator helps the teacher to plan the scenario of teaching learning process (the lesson plan), the teaching material and observation checklist, the genre of the text which will be applied, and the exercises given to the students would be determined in this stage. 2) Action stage. What the teacher have planned in the planning stage is implemented in this stage. The teacher gives the students a brainstorming or some pre-writing activities to enhance the students ${ }^{\text {ee }}$ ideas. Then the teacher explains about writing paragraph skill by using pictures briefly. After that, the teacher gives pictures to the students and asks them to write paragraph. 3) Observation Stage. While the students are doing the instruction, the teacher observes what is going in the teaching learning process using pictures as a media to improve students paragraph writing skill. 4) Reflection Stage. In this stage, the teacher and the collaborator analyzes the result of observation checklist during the observation stage. It is analyzed for the next planning, acting and so on for the next cycle. If the result of the first cycle is not appropriate or less than their base score, then the teacher continues to go to the next cycle with the hope that next cycle will show better result than the previous one. In this study, the teacher tries to solve the studentse problem in paragraph writing especially in writing topic sentence, writing supporting sentences, using grammar, and using cohesive devices. If the students writing result on the first cycle still shows several problems, at least, they just get a little improvement from their base score, then next cycle must be conducted.

This classroom action research was carried out at the tenth grader students of SMAN 1 Magetan in the Academic Year of 2018/2019. The subjects of this study were students of class X.MIPA-1 who were in the second semester. The class consisted of 34 students, 14 males and 20 females with average age of sixteen years old. There are two kinds of data that are used in this research, they are quantitative and qualitative data (Herawati, 2009: 57). The qualitative data are collected by observation, questionaires, interview, and document analysis. The quantitative data are gotten from individuals ${ }^{\text {ee }}$ score from the beginning of the research up to the end of the research. The researcher obtains quantitative data by giving tests. The results of the test are analyzed using descriptive statistics.

\section{RESULTS AND DISCUSSION}

The description above has provided the overview of research finding of the implementation of pictures media to improve the skill of paragraph writing. The research finding shows some important points as follows: (1) increasing of students ${ }^{\text {ee }}$ motivation in paragraph writing; (2) improvement of students ${ }^{\text {ee }}$ understanding in writing topic sentence and supporting sentences or developing of topic sentence; (3) improvement students ${ }^{\text {ee }}$ understanding in using correct grammar and conjunctions or cohesive devices; (4) improvement of teaching and learning situation; (5) improvement of students ${ }^{\text {ce }}$ paragraph writing; (6) increasing students ${ }^{\text {ee }}$ creativity and self confidence in paragraph writing. These six values can be classified into two main points as follows: 1) Improvement of students' paragraph writing ability. The implementation of picture postcards media can improve the students ${ }^{\text {ee }}$ skill or ability in paragraph writing. Pictures media deals with the process of finding/discovering the concept of knowledge by students themselves. The researcher uses process approach to apply paragraph writing. As Zemach \& Rumisek (2005: 3) states that paragraph writing process is a process to teach paragraph writing that allows students to write their own ideas with their own process. Brown (2001: 335- 336) says that there are the concepts to write paragraph in the process approach; (a) focus on the process of writing that 
leads to final written product; (b) help students to understand their own composing process; (c) help them to build repertoires of strategies for pre-writing, drafting, and rewriting; (d) give students time to write and revise; (e) place central importance on the process of revision; (f) let them discover what they want to write; (g) give them feedback throughout the composing process. And the students can use the same process for any kind of paragraph writing. Based on the statements above, it can be concluded that there are five steps of paragraph writing process: planning, making outline, drafting, revising, and rewreting. The steps are not separated and not happened in a sequence but they might occur at the same time. Some people may edit as they revise a draft, while others edit when the whole draft is completed. Still, others revise as they draft. As the term suggests, the teaching of paragraph writing focuses on what goes on when learners write and what the teacher can do to help the leaners get into a good paragraph writing. To achieve the purpose above, pictures media can be implemented in paragraph writing. The steps of using picture in teaching and learning paragraph writing can be combined with the process of writing. The students start by finding the concept of paragraph and its indicators by making analysis. It is hoped they would have deep understanding and longer retention. Finally, when they are asked to apply their concept in the real writing, they can create good writing. There are some indicators which show students ${ }^{\text {ee }}$ writing improvement from preliminary up to the third cycle, they are: a) The students were used to making planning by choosing the topic, outlining as basic of writing that could help them to develop their ideas, drafting to develop their ideas to become sentences or paragraph, revising to revise the draft to become good paragraph, rewriting as the last product of paragraph writing. b) The students tried to use appropriate grammar and conjunctions. c) The students tried to minimize the grammatical mistakes by checking and sharing with their friends and teacher. d)Thestudentse paragraph writing score improved from pre-test at pre research up to third cycle which can be seen in the following table:

Table 1. The Mean of inter rater score in Pre Research until Post-test in cycle 3.

\begin{tabular}{lccccc}
\hline Level & Pre research & \multicolumn{2}{c}{ Cycle 1 } & \multicolumn{1}{c}{ Cycle 2 } & \multicolumn{2}{c}{ Cycle 3 } \\
\hline Highest Score & 78 & 80 & 85 & 94 \\
\hline Average Score & 61.50 & 68.24 & 75.06 & 82.88 \\
\hline Lowest Score & 50 & 57 & 61 & 71 \\
\hline
\end{tabular}

Table 2. The Scores in Each Aspect of Paragraph Writing in pre research up to third cycle.

\begin{tabular}{ccccc}
\hline $\begin{array}{c}\text { Aspects of } \\
\text { Paragraph }\end{array}$ & Pre test & Cycle 1 & Cycle 2 & Cycle 3 \\
\hline $\begin{array}{c}\text { Topic sentence } \\
\begin{array}{c}\text { Supporting } \\
\text { sentence }\end{array}\end{array}$ & 13.49 & 13.49 & 13.49 & 13.49 \\
\hline $\begin{array}{c}\text { Grammar } \\
\text { cohesive }\end{array}$ & 23.11 & 23.11 & 23.11 & 23.11 \\
\hline Devices & 18.58 & 18.58 & 18.58 & 18.58 \\
\hline
\end{tabular}

Table 3. Comparison of the number of students achieve the passing grade in pre research up to third

\begin{tabular}{|c|c|c|c|c|c|}
\hline Explanantion & Passing grade & Pre test & Cycle 1 & Cycle 2 & Cycle 3 \\
\hline $\begin{array}{l}\text { Score above } \\
\text { passing grade }\end{array}$ & 75 & 75 & 75 & 75 & 75 \\
\hline $\begin{array}{l}\text { Score below } \\
\text { passing grade }\end{array}$ & 75 & 75 & 75 & 75 & 75 \\
\hline
\end{tabular}

From the table 3 , there were 30 or $88.20 . \%$ students could pass the passing grade while the rest 4 or $11.80 \%$ still could not pass the passing grade. It means that the implementation of pictures media can improve the studentsee paragraph writing skill. 2) Improvement of students' motivation in paragraph writing. Winkel (1996: 150) says that learning motivation plays an important role to promote the spirit of 
learning so that the students with high learning motivation have strong energy to perform learning. Moreover, Ur (1996: 19) asserts that it is important part of the teachers ${ }^{\text {ee }}$ job to motivate the learners. In addition, Brown (1994: 152) says that motivation is an inner drive, impulse, emotion, or desire that moves one to a particular action. In more technical teerms, he explains that motivation refers to the choices people makes as to what experiences or goals they will approach or avoid, and the degree of effort they will exert in that respect. The researcher suggests the teacher to improve the teaching and learning rocess in shaping a positive interest so the students will be motivated to learn.

The implementation of picture postcards media can also improve the students ${ }^{\text {ee }}$ motivation. In this study, the indicators that are used to evaluate the improvement of motivation were impulse, initiation, intensity, and persistence. The impulse helps the students motivated doing their paragraph writing. The students can explore the ideas from the pictures. Having initiatiation will motivate the students to arouse their ideas in developing the sentences so that the paragraph writing process will run fluently. They initiate to answer the teachers ${ }^{e e}$ questions and correct their friends ${ }^{\text {ee }}$ sentences. The intensity is the power to motivate the students writing paragraphs. The students practice more excercises in paragraph writing by describing people ${ }^{e e}$ s physical appearance, profession, and hobby based on the topic sentence, supporting sentences, correct grammar, and correct conjunctions. The persistence is the strength to write paragraphs continuously. They write paragraphs using some steps such as; planning, outlining, drafting, revising, and rewriting.

During teaching and learning process, The students are motivated in joining paragraph writing using picture. They have high enthusiasm and participation in writing topic sentence, writing supporting sentences, using correct grammar, and using correct cohesive devices (conjunctions). The improvement of students ${ }^{\text {ee }}$ motivation in paragraph writing through the use of pictures as media is better, by following proper steps in process approach i.e. planning, outlining, drafting, revising/editing, and rewriting/producing, the students get high motivation in paragraph writing skill. 3) The strength and weaknesses of pictures media. Unlike the common pictures, pictures have a different performance. Rava (1998) stated that pictures carry cultural, artistic, and historical information. In addition, the picture of most picture is absolutely attractive so that the students will be interested in getting the information on it. Besides, most of the pictures are completed with many expressions which can help the students to get a lot of information about the subject described that we cannot find in the common pictures. Hayes (2007) also stated that teachers may prefer to use pictures which are easily to find and available on the internet to make their own pictures. Moreover, the art pictures can serve as a useful aid in motivating students to communicate something meaningful in a practical context. The cultural content expands the imagination and the learner's perspective on the world, leading to the desire to offer comment and opinion and ask questions. So, it is very appropriately chosen as the media in teaching paragraph writing.

During applying pictures media in teaching paragraph writing, there were some benefits that could be taken, they were: (1) teaching writing was more enjoyble. Students could explore and express their ideas, (2) the students knew that writing is a process. It needed many steps to get a good result, (3) they could appreciate with their own and friendse ideas and writing, (4) the students were more active and creative in teaching and learning process. The class was really designed student-centered. Besides having strengths, pictures media also have weaknesses. Teaching writing is not easy, and it is not spontaneous. There are many steps that must be done following process approach. They are planning, outline, draft, revising, and rewriting. Writing paragraph by using pictures has several steps, so it needed long time to do. By using pictures media the writing needs longer time to do. It can not be finished in the once or twice meeting.

From those explanations, it can be said that pictures are appropriately chosen as the media in teaching paragraph writing to the tenth graders. Related to that case, Hill (1990:1) claimed that wellchosen visuals evoke an immediate response from learners in any class. It can be concluded that using pictures media in teaching paragraph writing can improve studentse personal competence because it can awake one ${ }^{\text {ec }}$ s self-confidence, interest, and motivation. Using picture is suitable for students with high motivation as it challenges students to broden their eagerness in studying and in its turn increases 
studentse $^{\text {ee }}$ learning achievement. And paragraph writing using picture has more strengths than weaknesses.

By considering the data analysis above, there are some conclusions that can be drawn. 1. Pictures media can improve students ${ }^{\text {ee }}$ paragraph writing skill of the tenth graders of Senior High School. There are some reasons why pictures media can improve studentse paragraph writing: (1) It can improve writing topic sentence. They would not be boring doing paragraph writing, because they had to begin writing following the steps from planning step where they could compose their ideas to become topic sentence. They could make paragraph step by step so they did not feel difficulty and made the condition of the class being interesting. By using planning step, the students got the ideas enjoyable. Moreover, they could write the topic sentence easily. (2) It can improve writing supporting sentences. The teacher showed some of their products. Some products in the last cycle were better than products in the second cycle. Almost all students could write using topic sentence, supporting sentences, using correct grammar, and using cohesive devices (conjunctions). All students had good understanding the function of the all steps to write paragraph writing like, making planning, outlining, drafting, revising, and rewriting. It made their writing matched with the topic sentence. In supporting sentences, the students had better improvement; they could use the right ideas to express the pictures. They explored their ideas very well to write supporting sentences. (3) It can improve the studentse grammar and cohesive devices. In grammar they could use pronoun based on its function. They could use possessive as object, and subject, while in noun phrase they could create it based on the English rules. Their better understanding of paragraph writingees indicators affected their score in writing. All students had good understanding the function of the all steps to write paragraph writing. It made their writing matched with the topic sentence, all students could write paragraph well based on the pictures by describing people se physical appearance, profession, and hobby. 2. The students motivation is better when the pictures are used to teach paragraph writing skill.

There are some reasons to prove about it: The students are usually active in the class, in showing their eagerness to the lesson, in answering the questions or in doing the exercises. They are not afraid to ask the teacher if they have some problem in connection with the lesson. They are also brave to show their opinion. No wonder, the students with high motivation usually succeed to get high achievement in their study. But, students with low learning motivation tend to be lazy to improve their study. It is difficult for them to express their opinion. If there is a question, they do not give good responds. They also do not want to study hard. They like to be passive students in the class. This makes their achievement in teaching and learning lower. Therefore, the students with the high motivation have higher paragraph writing skill.

\section{CONCLUSION}

This study revealed that the use of the pictures succeded in teaching and learning paragraph writing. It proves that the presence of the pictures as interesting activity increased the studentse attention and seriousness in doing paragraph writing task. The pictures also enhanced the studentse participation and interaction during the learning activities. This study also proves the efficacy of using pictures aided teaching and learning technique to improve the students ${ }^{\text {ee }}$ ability in paragraph writing. Their average score increased from 61.50 to 82.88 .

It can be concluded that using picture is an effective technique used to improve paragraph writing skill of the students of Senior High School, especially for the tenth graders of SMAN 1 Magetan. Related to the result of the students ${ }^{\text {ee }}$ creativity in paragraph writing, it is proved that the students having high motivation have better paragraph writing achievement. The use of pictures can help the teaching and learning process running well. The students are able to gain the ideas in writing a composition especially writing paragraphs by describing and understanding the pictures which are given by the teacher. The result of the research implies that teaching by using pictures media can improve students ${ }^{\text {ee }}$ paragraph writing skill for the tenth graders. The right techniques used to teach paragraph writing can make the process of teaching and learning more alive and conducive. It can be known from their motivation to study.

English Teaching Journal, Vol. 7, No. 1, June 2019: $1-8$ 
There are some suggestions which are addressed to the teachers, students, and other researchers which can be listed as follows: For the teachers, in order to get maximum result and effect on students ${ }^{\text {ee }}$ paragraph writing skills, the suitable choice of teaching technique can make the teaching and learning run well. The students will enjoy their class if the learning process is not boring. If the learning process is enjoyable, the students will understand the material more easily. If the students understand the material, the purpose of teaching and learning will be gained. Surely, it is one of the objectives of teachers in teaching. Teachers must be clever in choosing the techniques or approaches for teaching and learning process in the classroom. And the teacher can apply process approach to reach the students" high creativity in paragraph writing. Moreover, the teacher can find suitable approach for the students based on the students ${ }^{\text {ee }}$ characteristics. For the students, using picture media is not the only problem solving technique used to overcome students" problem in learning paragraph. It can be said, that using picture is included as one of good strategies to overcome the students" problem in improving the paragraph writing. Students are also suggested to know their own characteristics so that they can adjust themselves with the approaches or methods used by the teacher. It maybe also useful to have research with different studentse" $^{\text {ee }}$ condition on like students" habit or interest. The researcher realized that this research is not perfect yet, so the researcher hopes that other researchers can carry on further investigation dealing with the same field. The results of the study can be used as additional reference for further research that will give contributions in teaching writing.

\section{REFERENCES}

Ansley, D. (2007). Instructional media: Chalkboards to video. Retrieved March 28.2013 from http// learningforlifefsu.edu/ctl/explore/o nlineresources/does/chptr9. pdf

Beth, M and Lindy, L, (1998). Teaching Writing in Middle School: Tips, Tricks, and Techniques. Teacher Ideas Press A Devision of Libraries Untimeted,Inc. Englewood, Colorado, USA.

Bailey, S. (2003). Academic Writing: A Practical Guide for Students. New York: Nelson tornes Ltd.

Brown, H. Douglas, 2000. Teaching by Principles: An Interactive Approach to Language Pedagogy. San Fransisco: Longman.

Brown, H. D. (2004). Language assessment: Principles and classroom practices. White Plains, NY: Pearson Education.

Brown, J., Lewis R.B., \& Harcleroad, F.F. (1983). Audio visual instruction. Ney York: McGrawHill Book Inc.

Heaton, J. B. 1989. Writing English Language Tests. New York: Longman, Inc. http://www.picturescollecting.co.uk/ppm online/ppm 12 feb.pdf. Accessed on August 2, 2012.

Jean, E., MA. \& Emily, Dotson B., 2009. Writing: Grammar, Usage, and Style. www.cliffsnotes.com.Kellner, H., 2009. Using Photography to inspire writing. Retrieved July 30, 2012 from http://www.creativity portal.com/prompts /using- photography177inspire-writing.html.

Munadi, Y., 2008. Media Pembelajaran: Sebuah Pendekatan baru. Jakarta: Gaung Persada Press.

Oshima, A., 2006. Writing Academic English (4th ed). New York: Pearson Education.

Richards, J., 2006. Communicative Language Teaching Today. NitroPDF* Professional.

Richards, Jack C and Rodger, Theodore S., 2001. Approaches and Methods in Language Teaching. Cambridge: Cambridge University Press.

Ur, Penny, 1996. A course in Language Teaching. Cambridge University Press.

Weir, Cyrill J., 1988. Communicative Language Testing. Prentice Hall Europe.

Yale, J. B., 2010. The relationship between reading and writing. Retried July 11, 2018 from http://www.12reader.com/the- relationship-between-readingand- writing. 
Yang, J.T., 1995. An Outline Scientific Writing. For Researchers with English as a Foreign Language. Singapore: World Scientific Publishing Co. Pte. Lte.

Zemach \& Rumisek, 2005. Academic Writing from paragraph to essay. New York: Macmillan Publishing Company.

Utami, Zuliati, Furaidah, 2016. Bahasa Inggris SMA/MA/SMK/MAK Kelas X. Jakarta: Kementrian Pendidikan Dan Kebudayaan. 